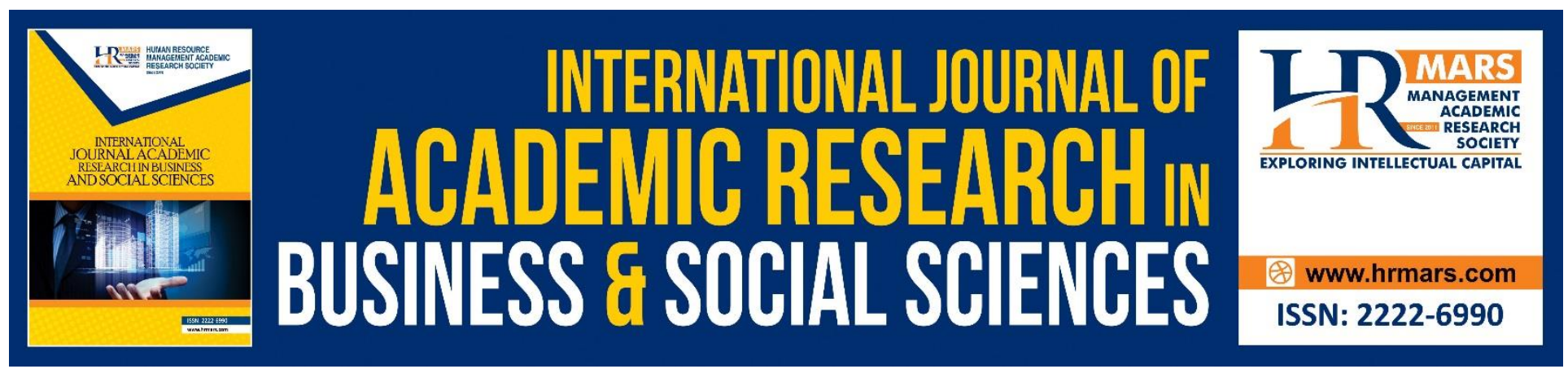

\title{
Setting the Public Agenda: An Analysis of the Singapore Free Press Portraying the Malays during Colonial Period
}

\author{
Abdul Mutalib Embong, Zulqarnain Bin Abu Bakar, Ahmad Murad Noor \\ Merican, liani Hussain
}

To Link this Article: http://dx.doi.org/10.6007/IJARBSS/v9-i2/5661

DOI: $\quad 10.6007 /$ IJARBSS/v9-i2/5661

Received: 22 Jan 2019, Revised: 19 Feb 2019, Accepted: 08 March 2019

Published Online: 14 March 2019

In-Text Citation: (Embong, Bakar, Merican, \& Hussain, 2019)

To Cite this Article: Embong, A. M., Bakar, Z. B. A., Merican, A. M. N., \& Hussain, L. (2019). Setting the Public Agenda: An Analysis of the Singapore Free Press Portraying the Malays during Colonial Period. International Journal of Academic Research in Business and Social Sciences, 9(2), 1024-1033.

Copyright: (c) 2019 The Author(s)

Published by Human Resource Management Academic Research Society (www.hrmars.com)

This article is published under the Creative Commons Attribution (CC BY 4.0) license. Anyone may reproduce, distribute, translate and create derivative works of this article (for both commercial and non-commercial purposes), subject to full attribution to the original publication and authors. The full terms of this license may be seen at: http://creativecommons.org/licences/by/4.0/legalcode

Vol. 9, No. 2, 2019, Pg. 1024 - 1033

Full Terms \& Conditions of access and use can be found at http://hrmars.com/index.php/pages/detail/publication-ethics 


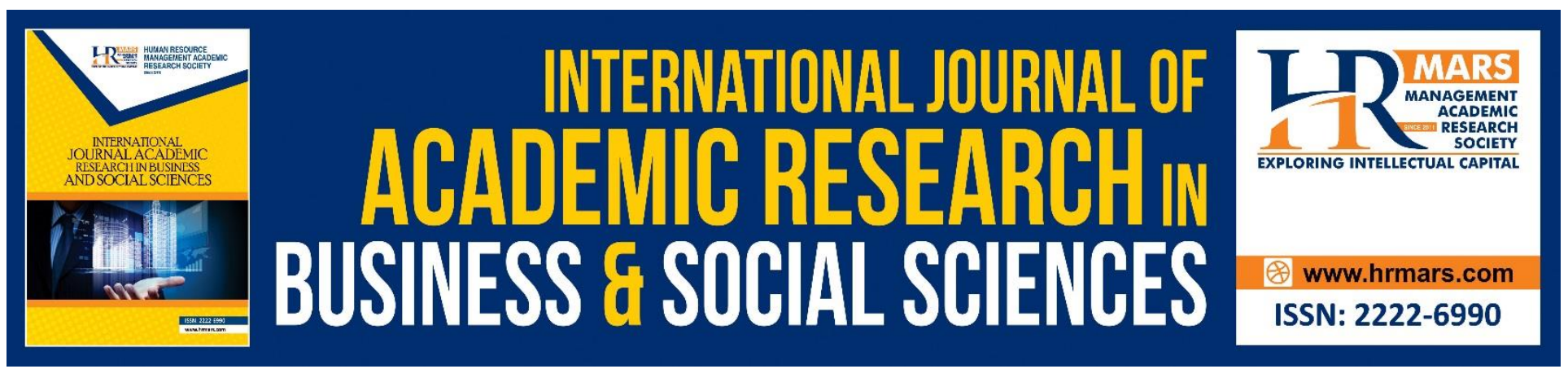

\title{
Setting the Public Agenda: An Analysis of the Singapore Free Press Portraying the Malays during Colonial Period
}

\author{
Abdul Mutalib Embong \\ Universiti Teknologi PETRONAS, Perak, Malaysia \\ Zulqarnain Bin Abu Bakar \\ Universiti Teknologi PETRONAS, Perak, Malaysia. \\ Ahmad Murad Noor Merican \\ Universiti Teknologi PETRONAS, Perak, Malaysia. \\ Juliani Hussain \\ TATIUC, Terengganu, Malaysia.
}

\section{Abstract}

This study examines how British colonial writers penned on their views towards the native Malays during colonial time. Thematic Content Analysis is used and the findings portraying Malays were deliberated. The extracts and full articles taken from Singapore Free Press (from the beginning till the last edition before Second World War), revealed the Malays were portrayed negatively in many aspects. Amongst were lazy (or lassitude, lethargic or peasant or indolent) stupid, uneducated, barbaric and ferocious. The language in the agenda was set to indoctrinate the Malays with a sense of dependency and inferiority. This had imperative allegations for the post-colonial nation states. It indicated that issue attributes salient in the media was functioning as a significant dimension to legalise the colonialism and how Agenda Setting playes its role.

Keywords: Malay, Lazy, Stupid, Singapore Free Press, British, Colonialism, Agenda Setting

\section{Introduction}

The British largely practiced a non-interventionist policy before the late 19th century. Somehow two main factors which are: fluctuating supply of raw materials, and security, drove British to play a more active role in the colonized land, such as Africa and Asia. British moved further to 
South East Asia and started to establish bases in new settlements in British Malaya: Jesselton, Kuching, Penang and Singapore. As they came, British brought along newspapers to communicate among themselves. Thus, it brings to the study of discourse from printing press is not limited to an explicit account of an isolated textual or dialogical structures per se. Precisely, developments in the study of discourse can be seen in diverse disciplines as speech communication, cognitive psychology, social psychology, microsociology, and ethnography. It is a rather a complex communicative event that also embodies a social context, featuring participants (and their properties) as well as production and reception processes (Brennan, 1985). The discourse of the British through their newspapers can be seen how they looked at the Malays.

For the past 5,000 years, Malay civilization has been residing in the South East Asia. Indeed, the advent of the Malacca Sultanate in the 15th century triggered a major revolution in Malay history, the significance of which lies in its far-reaching political and cultural legacy. This is where Malacca became the centre of attraction in this side of the world, having trading affairs, and diplomacy with powerful empires from east and west. Industrial Revolution initiated in 17th century has made European big powers to colonise the Malay region starting with the Portuguese in 16th century which they attacked and landed their base in Malacca. Soon after that, the Malay land became like pieces of cake to be shared amongst them.

British needed to find a solid and concrete reason to legalize the colonialism on the native Malays. The Malays had shown their rebellions towards the British after they conquered and deceived the Malay Royal Rulers (Gullick, 1953). Thus, British need to come out with certain excuses to dominate the Malay land and the people. Publications of printing press was one way to set their agenda.

\section{Rationale}

This paper is built on a simple premise: How the British managed to portray certain negative traits towards the Malays during the colonial period. The traits of Malay character were not explained in a historical and sociological manner. Most of the writers were the colonists themselves, thus they rarely gave an unambiguous expression of their views. They often mixed environmental, cultural, and genetic interpretations of ethnic differences in their prospect. Apart, they also had their hidden agenda giving such remarks to the Malays which would be explained in this paper.

\section{Objectives:-}

The Research questions of the paper are as the following:

1) How Agenda Setting Theory was used by British Colonial writers in depicting the Malays during British colonization through their English newspapers?

2) What values were given to the Malays during this phase?

\section{Methodology}

The ontology of this study is qualitative in nature, by referring to the secondary data - articles from The Singapore Free Press. The printing mass media is chosen because of its the importance in daily routines comparing to other printed materials. The role of newspapers is very dominant too as it showed the historical and sociological phenomenon. In add, the printed media has bigger and faster circulation among the audiences, plus it becomes the most powerful tool to express ideas and 
INTERNATIONAL JOURNAL OF ACADEMIC RESEARCH IN BUSINESS AND SOCIAL SCIENCES

Vol. 9, No. 2, Feb, 2019, E-ISSN: 2222-6990 C 2019 HRMARS

information. The methodology used in this paper is Thematic Content Analysis. The word "Malay" is the key. It is used to analyse classifications and present themes (patterns) that relate to the data. It also can illustrate the data in great detail and deal with diverse subjects via interpretations. Besides, Thematic Content Analysis is commonly used in journalism discourse too.

\section{Findings}

The findings would give some glimpses through the excerpts about the Malays from the articles of that newspapers. These were written by the British writers to describe the Malays. The articles were chosen based on the number of frequency they appeared in the English language Newspaper - The Singapore Free Press. The excerpts were places under certain categories or themes which describing the Malays characters from the

British eyes:

Table 1: The Excerpts from The Singapore Free Press According to Certain Categories or Themes

\section{Category: Lazy / Passive / Slow / Indolence}

It has been often asserted that the Malays are too indolent by nature to be able to hold their own against the more enterprising Asiatic races with whom circumstances make it necessary that they should compete. (Stoney, The Future of the Malays", 1833, February 21, p. 8)

\section{Category: Negligence}

Mohamed Ali, the Malay chauffeur, was produced in the Third Court yesterday on a charge of rash and negligent driving and remanded a week for trial. ("The Singapore Free Press and Mercantile Advertiser 1884-1942, 1922, October 31, p. 12)

\section{Category: Violence / Crime}

Serious charges are pending against a Malay woman who is alleged to have caused the death of a Malay whom she stabbed on the chest on Sunday night. ("Police Courts", 1925, June 23 p. 9)

\section{Category: Unreliable}

The two Malay police constables who were charged in connection with the escape of a prisoner (held on a charge of attempted murder) from the Tan Tock Seng hospital, and who claimed trial, was convicted by Mr. Muddie, the district judge, yesterday. (“A Prisoner's Escape”, 1927, May 7, p. 20)

Category: Uneducated 
INTERNATIONAL JOURNAL OF ACADEMIC RESEARCH IN BUSINESS AND SOCIAL SCIENCES Vol. 9, No. 2, Feb, 2019, E-ISSN: 2222-6990 C 2019 HRMARS

The Malay is 40 percent literate. Of course that means in his own language, learned through reading the Koran with his priest as a teacher. Aside from his religious ambitions, he has shown no desire to struggle for an education. But the British government has set itself to make education attractive and accessible to the native. (Stoney, Mostly Malay, 1925, July 16, p. 14)

\section{Category: Lethargic}

Lethargic Sikhs and Malays, bad-tempered Indians and insolent Chinese become energetic, goodtempered, and respectful. (“Our Constables' Public School”, 1930, September 16, p. 10)

\section{Category: Treacherous}

...but here again the enterprising adventurer is met, not only by treacherous Malays, but also by tigers and other wild beasts... (“Europe", 1847, December 12, p. 1)

\section{Category: Uncivilized / Nondependent}

We are introduced to the bad old state of things in which the Malays of the west coast are alluded to as fisherman, hunters, pirates and despoilers of one another's peace and provinces, carrying their differences up and down their long rivers or confining them with "slaughterous" results within their tiny kampongs or villages. ("The Singapore Free Press and Mercantile Advertiser 1884-1942, 1908, August 21, p.4)

\section{Category: Debt / Borrow Money}

In short, if they can beg, borrow or steal for the sake of smoking opium and gambling, they are perfectly gratified. (Wright, Byegone Days in Malaya XI, 1912, March 19, p. 3)

\section{Category: Superstitious}

On the other hand, he found them to be excessively credulous and superstitious, fond of external pomp and show, very revengeful, somewhat impatient of control, and unwilling to submit to insult. (Crawford, Malaya as A Possible Recruiting Ground for The Indian Army, 1895, July 20, p. 3)

\section{Category: Amok}

...special love of gambling, combine to give rise to those act of desperate excess which are known to us by the term of running amuck (amok) and which are universal throughout the archipelago. The most usual form of Amok appears to be when the desperado attacks indiscriminately friend and foe, killing and wounding all whom he meets, until he is killed himself (Crawford, Malaya as $A$ Possible Recruiting Ground for The Indian Army,1895, July 20, p. 3) 


\section{Category: Capability}

As regards their moral qualities, he found Malays to be more truthful, more capable of attachment and more simple in their manners than other eastern nations; having no capacity for intrigue like other Asiatic and being neither litigious, avaricious nor rapacious. (Crawford, Malaya as A Possible Recruiting Ground for The Indian Army,1895, July 20, p. 3)

To sum up the findings, it was notable that British put certain values or negative remarks regarding the Malay characters. That was how they saw and perceived the Malays. In short, Malays were portrayed with negative characteristics.

\section{Discussions}

\section{Mass Media's Political Agenda Setting Power}

This section will justify the main possible reason leading to accusation of Malays' bad characters. Firstly, we need to examine meticulously the history of colonialism itself. It all began in the 16th century, in which the time European reached Southeast Asia, and where the ebb and flow of country's kingdoms and territories had taken place. There were wide trading linkages among the populations within the regions. Port cities in Sumatra and the Malay Peninsula contained not only peoples from throughout the Indonesian archipelago, but also from China and India (Lamb, 1964; Reid, 1980; Wheatley, 1961).

There was a major demand for the raw materials which could not be fulfilled by the traditional systems, bringing to the competitions and the need to control the supply and production of raw materials among the European imperialists. It also led to the need of expansion of power over the natives in this region. The developing in economics could be seen not only in term of raw materials but also the markets, capital and labours. The latest structural administrative forms were prepared and arranged throughout Southeast Asia.

It marked the expanded grip British colonial system over the entire Malay Peninsula. The British would never compromise with any other powers over the region. They needed a strategy to rule. One was by practicing colonialism and subsequent inter-ethnic relationships among the people in the Malay Peninsula, which had significantly brought the images of the Malays and others.

The idea of change in colonial ideology in the late 19th century is a hypothesis that can be tested, at least in an approximate fashion, by an examination of the writings of Europeans in Malaya during this period. This, as being discussed earlier, had been shown in the articles from Singapore Free Press which were the central focus in this paper.

A fundamental methodological problem in this inquiry is that most authors rarely gave an unambiguous expression of their views-they often mix environmental, cultural, and genetic interpretations of ethnic differences. There were definitely the clashes of ideas what the authors see upon the subjects as they come from two different backgrounds. Besides, it is hard to assess the statements of a few individual writers as representing a larger climate of opinion. Drawing upon their own experiences and insights, the writers can and do vary from the prevailing ideology of an era. 
INTERNATIONAL JOURNAL OF ACADEMIC RESEARCH IN BUSINESS AND SOCIAL SCIENCES

Vol. 9, No. 2, Feb, 2019, E-ISSN: 2222-6990 C 2019 HRMARS

Some individuals may be ahead or behind their times in expressing their views. And many writers test this hypothesis with an examination of changes in the ethnic classification used in the censuses of colonial Malaya (Hirschman, 1986; Alatas, 1977).

\section{Language in Agenda Setting}

By 19th century the literacy level has been reduced in a great percentile as the education awareness was common. It was an eye opener to some of Malay scholars who tried to reveal the truth of colonization and imperialism. Some of them were against the idea how history was written by the British. As they themselves were the subject matter, these people experienced the "story plot" of the written text.

The foundation of the new approach was an attack on the premise that, using the exercise of reason, one might discover universal truths about the human condition. Instead, it was proposed that all knowledge is relative, and that there is no objective truth. Indisputably, the truth, facts and reality were scrapped away by the Europeans, which was subject substantively by a series of agenda. Literary devices, language or vocabulary in such written text show this attitude (Mustapha Hassan, 2014).

This paper focuses on Agenda Setting Theory and how it played its role in shaping the British views towards the Malays. It is an idea where such inventions of the truths are motivated by a need to create power positions over other peoples specially the one in the colonial land. This was happening in the Malay land as early as 16th century when the British came to the region for the trade, getting new land and expanding power. To prevent other European powers at that time conquering the Malay land for the same interest, the British adapted an idea of "Orientalism " to legalize their act to conquer the Malay Peninsula by giving them excuses to "help" civilizations towards the native Malays. They carried along their mantra - "White Man's Burden"2" and also newspapers to project and criticize how "awful" the Malay were.

When they mentioned 'natives', they connoted a collection of negative term: violent, clannish, horde manners, ill-educated, unreasonable, childish, criminal, gambling, filthy, amoral, and orthodox. In short, the colonial histories have either been too verbose and antiquarian in their character, or too superficial and incorrect to be looked at.

Throughout the work, there was a desire to seek out the methods of imperialist power through the language that being used. The identification of colonisers and colonised, for example, were given masculine and weak criteria. Englishmen were "macho", sturdy, ingenious and valiant;

\footnotetext{
1 Orientalism is a theory that associated to few phenomena where a way Western dominate, restructure, and control the East. It is a style of thoughts based on the ontological and epistemological distinctions made between the East (the orient) and the West (the Occident). Orientalism can also be discussed and analyzed as a legal entity to face the East, with the interest to make a statement about the East, to confirm the views about the East, describing, positioning, and then mastering it. Orientalist claims that he has broad knowledge about the people of the East, its philosophy and civilization.

2 The White Man's Burden brings an idea and strong message that over the many periods of British's rule and had become laced through their literature and knowledgeable discourse. The idea stimulates the British to be prodigious people, exploring what the outside Britain can offers and do something good for the others out there who are less superior and weak. Most of the European Empire used the message in a form of denying the ability of the portrayed people to rule and govern their own land. White Man's Burden legalise the denial the ability to portray the people to rule and govern their own land. At the same time what so-called scientific theories of race were used to establish the partition of labour in Malay land.
} 
INTERNATIONAL JOURNAL OF ACADEMIC RESEARCH IN BUSINESS AND SOCIAL SCIENCES Vol. 9, No. 2, Feb, 2019, E-ISSN: $2222-6990$ ๑ 2019 HRMARS

natives were portrayed stupid, lazy, feeble, gutless and even effeminate. It was argued that it was so powerful and be addressed as "colonial discourse", it had changed not only the way of thinking of the colonisers, but also of the colonised. It has set the two different standards and prolongs from century to another.

The language in the agenda was set to indoctrinate the native with a sense of dependency and inferiority. This, it was felt, had imperative allegations for the post-colonial nation states.

As the revolution industry in Europe grew by the middle of the nineteenth century, there was a great need to get the supplied of raw materials and tin which were abundant in Peninsula Malaya. The vast last of the continent also provided timbers and can be a good potential land for an agricultural development.

The idea of claiming Malays as "stupid" is actually baseless because as a race that knew the hierarchy of administration, the Malay rulers had started as early as 2 nd and 3rd AD century, and the most pertinent one like Malacca sultanate, which covered most of Malay land in south east Asia by 14th century, the famed Langkasuka that dominated the northern part, and not to forget some other sultanates after the fall of Malacca to Portuguese in 1511. Later on, the kingdom developed and by 17 th century, The Malay kingdoms realized commercial interests in the Straits Settlements. They ${ }^{3}$ had begun to improve this prospective by taking in Chinese labour to enlarge tin production. The Chinese from the main land China were brought in to work at the tin mines. The needed of rubbers contributed to the opening of rubber plantations and again the Chinese labour were required to do the plantation work (Reid, 2001).

Besides, traditional rivalries among Malay chiefs and disputes among the various Chinese groups were exacerbated by competition for the immense economic gains to be had by control of tin production (Khoo, 1972). Sporadic fighting, usually between one Malay-Chinese coalitions against another Malay-Chinese faction, led to frequent disruptions in tin production. With heavy investments in the Malay states, merchants in the Straits Settlements continually pressed for British intervention to provide "stable government". This definitely was not welcome by the British who wanted to conquer such wealth. Their intention and plan to monopoly the economic and political controls were not running smoothly because of these interferences.

Finally, in a complex series of political and military moves, beginning with the Pangkor Agreement in 1874, the British took effective control of three west coast states in the mid-1870s (Cowan, 1961; Parkinson, 1960). Under the fiction of conveying British advisors to the Malay Sultans, the colonial government recognized direct management over virtually all government parts. The procedure did not go smoothly as reflective interpretations make it seem.

There was armed Malay resistance in Perak, Selangor, and Sungai Ujong in 1875, and later in Pahang (Gullick, 1954; Parkinson, 1960: Chap. 10-11; Clifford, 1929, p. 3-75). But with a disunited Malay aristocracy and the force of superior arms, the British were able to consolidate their colonial administration in a fairly brief time. Again, British mirrored these people as weak, uncivilized and barbaric that needed helps.

\footnotetext{
${ }^{3}$ The arrivals of the Chinese in the Malay Peninsula can be explained as having occurred under three major waves: 1,2 and 3. This is based on studying the lingua franca of the Chinese in Peninsular Malaysia, and determining why in some cities, there are Chinese communities that speak Baba Malay, in other cities, there are two different types of Hokkien spoken, while in yet others, Cantonese predominates. The founding of a Malay sultanate in Malacca (1400-1511) greatly enhanced economic activities between Malacca and the surrounding regions including China, particularly its southern provinces.
} 
The agenda setting set up by the British through language finally worked and British colonial system expanded its grip over the entire peninsula, The United Kingdom was responsible for foreign affairs and defence of the federation, whilst the states continued to be responsible for their domestic policies (Mustapha Hassan, 2014). Even so, the British Resident General would give advice on domestic issues, and the states were bound by treaty to follow that advice (Mustapha Hassan, 2014). Such act and move were prolonging till the occupation of Japan in 1942-1945 to ensure the domination of the British power in the Malay land.

\section{Conclusion}

The language was set to indoctrinate the native with a sense of dependency and inferiority. This, it was felt, had imperative allegations for the post-colonial nation states. By picturing the native Malays as a weak nation, the agenda set towards them worked. It ensured and legalised the colonialism in the Malay land and as a result, British enjoyed the luxury in here to bring back to their homeland.

These images had been disseminated among countless thousands of minds more than four centuries by hundreds of books and endless verbal communications. The worse, these images still have a substantial impact after the independence. It is bewildering that no thoughtful work has been done to study the roots and allegations of such images. To adjourn this last sentence, this paper perhaps is one of the starting points towards that effort.

\section{Corresponding Author}

Abdul Mutalib Embong, Universiti Teknologi PETRONAS, Perak, Malaysia.

Email: mutalib_embong@utp.edu.my

\section{References}

A Prisoner's Escape, The Singapore Free Press and Mercantile Advertiser (1884-1942), 1927, May 7, p. 20

Alatas, S. H. (1977). The Myth of the Lazy Natives, University of Singapore. Retrieved from http://www.cis-ca.org/voices/a/attas-mn.htm

Brennan, M. (1985). Class, Politics and Race in Modern Malaysia In R. Higgot \& R. Robinson (Eds). Southeast Asia: Essays in the Political Economy of Structural Change. Malaysia

Clifford, H. (1966). Stories by Sir Hugh Clifford, (Selected and introduced by William R. Roff). Kuala Lumpur: Oxford University Press.

Cowan, C. D. 1961. Nineteenth century Malaya: the origins of British political control. London: Oxford University Press

Crawford. (1895, July 20). Malaya as a Possible Recruiting Ground for The Indian Army. Retrieved from Singapore Free Press:

http://eresources.nlb.gov.sg/newspapers/Digitised/Article/singfreepressb189507201.2.18?

Gullick, J. M. (1953). Captain Speedy of Larut. Singapore: Malaya Pub. House 
INTERNATIONAL JOURNAL OF ACADEMIC RESEARCH IN BUSINESS AND SOCIAL SCIENCES

Vol. 9, No. 2, Feb, 2019, E-ISSN: 2222-6990 C 2019 HRMARS

Mustapha Hassan, A. (2014, October). Revisiting The Theory of the Lazy Malays! Retrieved from

http://malaysiasupport.blogspot.my/2014/10/revisiting-theory-of-lazy-malays.html on 12

July 2017

Our Constables' Public School, The Singapore Free Press and Mercantile Advertiser (1884-1942), 1930, September 16, p. 10

Parkinson, C. N. (1960). British Intervention in Malaya 1867-1877. Singapore: University of Malaya Press.

Police Courts, The Singapore Free Press and Mercantile Advertiser (1884-1942), 1925, June 23 p. 9

Reid, A. (2001). Sojourners and Settlers: Histories of Southeast Asia and the Chinese. Hawaii: University of Hawaii.

Stoney, B. O. (1833, February 21). The Future of the Malays. Retrieved from http://eresources.nlb.gov.sg/newspapers/Digitised/Article/singchronicle183302211.2.13? 